University of Pennsylvania Carey Law School

Penn Law: Legal Scholarship Repository

Faculty Scholarship at Penn Law

7-27-2007

\title{
The American Model Penal Code: A Brief Overview
}

Paul H. Robinson

University of Pennsylvania Carey Law School

Markus D. Dubber

University at Buffalo Law School

Follow this and additional works at: https://scholarship.law.upenn.edu/faculty_scholarship

Part of the Criminal Law Commons

\section{Repository Citation}

Robinson, Paul H. and Dubber, Markus D., "The American Model Penal Code: A Brief Overview" (2007). Faculty Scholarship at Penn Law. 131.

https://scholarship.law.upenn.edu/faculty_scholarship/131

This Article is brought to you for free and open access by Penn Law: Legal Scholarship Repository. It has been accepted for inclusion in Faculty Scholarship at Penn Law by an authorized administrator of Penn Law: Legal Scholarship Repository. For more information, please contact PennlawIR@law.upenn.edu. 


\title{
THE AMERICAN MODEL PENAL CODE: A BRIEF OVERVIEW
}

\author{
Paul H. Robinson* and Markus D. Dubber ${ }^{\star \star}$
}

If there can be said to be an "American criminal code," the Model Penal Code is it. Nonetheless, there remains an enormous diversity among the fifty-two American penal codes, including some that have never adopted a modern code format or structure. Yet, even within the minority of states without a modern code, the Model Penal Code has great influence, as courts regularly rely upon it to fashion the law that the state's criminal code fails to provide. In this essay we provide a brief introduction to this historic document, its origins, and its content.

\section{INTRODUCTION}

Within the United States, there are fifty-two American criminal codes, with the federal criminal code overlaying the codes of each of the fifty states and the District of Columbia. Under the U.S. Constitution, the power to impose criminal liability is reserved primarily to the states, with federal authority limited to the prohibition and punishment of offenses specially related to federal interests (including crimes committed on property of exclusive federal jurisdiction such as military bases, crimes against certain federal officers, and crimes that involve conduct in more than one state that is difficult for a single state to effectively prosecute, such as drug

${ }^{*}$ Colin S. Diver Professor of Law, University of Pennsylvania.

***Professor of Law \& Director, Buffalo Criminal Law Center, State University of New York at Buffalo.

New Criminal Law Review, Vol. 10, Number 3, pps 319-341. ISSN 1933-4192, electronic ISSN 1933-4206. () 2007 by the Regents of the University of California. All rights reserved. Please direct all requests for permission to photocopy or reproduce article content through the University of California Press's Rights and Permissions website, http://www.ucpressjournals. com/reprintInfo.asp. DOI: 10.1525/ndr.2007.I0.3.319. 
and organized crime offenses). ${ }^{1}$ The vast bulk of crimes and essentially all "street" crimes-homicide, rape, robbery, assault, and theft-fall under jurisdiction of one of the fifty state criminal codes or the code of the District of Columbia.

There is much diversity among the fifty-two American criminal codes and, therefore, it is often difficult to state "the" American rule on any point of criminal law. But there also are many similarities among the codes, in large part due to the influence of the American Law Institute's Model Penal Code. Promulgated in 1962, the code prompted a wave of state code reforms in the 1960s and 1970s, each influenced by the Model Penal Code.

Some of the Model Penal Code provisions have not been widely accepted. For example, while the Model Penal Code generally rejects the common law's "felony murder" rule, which in its broadest form holds all killings in the course of a felony to be murder, most states have retained the rule. Similarly, a majority of states have rejected the Model Penal Code's innovation in prescribing the same punishment for inchoate offenses, such as attempt, and consummated offenses.

Nonetheless, the Model Penal Code is the closest thing to being an American criminal code. The federal criminal code is too unsystematic and incomplete in theory and too irrelevant in practice to function as a national code. Where states have not followed the Model Penal Code, the divergences locate points of controversy that often continue today. And the code and its commentaries have been the intellectual focus of much American criminal law scholarship since the code's promulgation. ${ }^{2}$

\section{THE HISTORY OF THE MODEL PENAL CODE}

The Model Penal Code was not the first or the most ambitious, but far and away the most successful attempt to codify American criminal law. To appreciate the Model Penal Code's significance, it must be placed within the

I. More specifically, the states' criminal law power derives from their "police power." The federal government has no police power and therefore must rest its criminal-law making on other grounds, most notably the power to regulation interstate commerce. See Markus D. Dubber \& Mark G. Kelman, American Criminal Law: Cases, Statutes, and Comments 2-3 (2005); see generally Markus D. Dubber, The Police Power: Patriarchy and the Foundations of American Government (2005).

2. See generally Markus D. Dubber, Criminal Law: Model Penal Code $\$ \$$ I-2 (2002); Paul H. Robinson, Criminal Law $\$ 2.I (1997). 
spotty history of American criminal codification. ${ }^{3}$ Unlike the development in continental Europe, modern criminal law in the United States did not arrive in the form of criminal codes. Rather than concern themselves with the threat of punishment, American reformers pragmatically proceeded directly to reform the punishment itself. In the new field of corrections, Americans led the way. As a French resident of Philadelphia noted admiringly in 1796, "the attempt at an almost entire abolition of the punishment of death, and the substitution of a system of reason and justice, to that of bonds, ill-treatment, and arbitrary punishment, was never made but in America." As early as 1776 , Thomas Jefferson had drafted a bill for the Virginia legislature that called for punishment based on the theory of prevention outlined by Cesare Beccaria and developed by Jeremy Bentham. ${ }^{5}$ The final two decades of the eighteenth century brought the establishment of solitary confinement prisons in Philadelphia and then in New York and other states, including Virginia. I823 saw the opening of the prison in Auburn, New York, to which visitors flocked from around the world, including Alexis de Tocqueville. ${ }^{6}$

American criminal codes were first compiled by Edward Livingston and later David Dudley Field. Livingston's elaborate drafts for a federal criminal code and a Louisiana criminal code, completed in 1826 , were both the most ambitious and the least successful efforts at criminal law codification in the United States. Livingston's penal code was Benthamite both in scope and in substance. The penal code was divided into four separate codes comprising all aspects of penal law, from the definition of penal norms in a "Code of Crimes and Punishments," to the imposition of those norms in a "Code of Procedure" and a "Code of Evidence," and eventually

3. For a more detailed treatment of the history of Anglo-American criminal codification, see Sanford H. Kadish, Codifiers of the Criminal Law, in Blame and Punishment: Essays in the Criminal Law 205 (1987).

4. François-Alexandre-Frédéric La Rochefoucauld-Liancourt, On the Prisons in Philadelphia 33 (1796) (quoted in Louis P. Masur, Rites of Execution: Capital Punishment and the Transformation of American Culture, 1776-1865, at 71 (1989)).

5. For a critical appraisal of Jefferson's draft, see Markus D. Dubber, "An Extraordinarily Beautiful Document": Jefferson's Bill for Proportioning Crimes and Punishments and the Challenge of Republican Punishment, in Modern Histories of Crime and Punishment (Markus D. Dubber \& Lindsay Farmer eds., 2007).

6. See Gustave de Beaumont \& Alexis de Tocqueville, On the Penitentiary System in the United States and Its Application in France (1833). 
to the actual infliction of sanctions in a "Code of Reform and Prison Discipline."7 Each aspect of the penal law, and each corresponding code, was individually, and as a system, designed to rationalize penal law on the utilitarian principle that Bentham had derived from Cesare Beccaria's famous treatise On Crimes and Punishments: la massima felicità divisa nel maggior numero. ${ }^{8}$

David Dudley Field was both far less ambitious, and far more successful, as a criminal codifier. A successful New York lawyer, Field's codification efforts extended beyond the penal law and reflected pragmatic concerns about the accessibility of law, most importantly to lawyers.' Field's codes were designed to simplify legal practice by sparing attorneys the tedium of having to sift through an ever rising mountain of common law opinions. As a result, Field was more concerned with streamlining than he was with systematizing or even reforming New York penal law. Field's New York Penal Code was submitted to the legislature in 1865 , and passed into law in I88I. ${ }^{10}$ It remained in force until it was replaced by the New York Penal Law of 1967 .

That New York Penal Law, like the revised criminal codes of many other states, was based in large part on the American Law Institute's Model Penal Code, which had been published in 1962. In fact, Herbert Wechsler, the Chief Reporter of the Model Penal Code, served on the legislative commission that drafted the New York code. ${ }^{11}$

The Model Penal Code combined Livingston's systematic ambition and integrated utilitarian approach with Field's pragmatism and legislative success. When the Model Penal Code project was launched in 195I, the vast majority of American criminal codes were in a sorry state. Only Louisiana had undertaken a serious effort to reform its criminal code since

7. See Edward Livingston, The Complete Works of Edward Livingston on Criminal Jurisprudence (1873).

8. Cesare Beccaria, Dei delitti e delle pene (1764). On the relation between Bentham and Beccaria, see H.L.A. Hart, Bentham and Beccaria, in Essays on Bentham: Studies in Jurisprudence and Political Theory 40 (1982).

9. New York Field Codes (1850-1865).

10. 4 New York Field Codes (1850-1865).

II. See generally Richard Bartlett, Criminal Law Revision Through a Legislative Commission, I8 Buff. L. Rev. 213 (1968-1969); Richard Denzer, Drafting a New Penal Law for New York, I8 Buff. L. Rev. 25I (1968-1969). 
the nineteenth century. ${ }^{12}$ A typical American criminal code at the time was less a code and more a collection of ad hoc statutory enactments, each enactment triggered by a crime or a crime problem that gained public interest for a time. What passed for a major "reform" in that period was the federal criminal code in 1948 putting the offenses in alphabetical order. Faced with this state of affairs, the American Law Institute's decision to draft a Model Penal Code was an ambitious undertaking.

The American Law Institute (ALI) is a nongovernmental organization of highly regarded judges, lawyers, and law professors in the United States. The institute typically drafts a "restatement" of an area of law, which articulates and rationalizes the governing rules in American jurisdictions. When published, the ALI "Restatement of the Law" for a particular area often becomes persuasive authority for courts and legislatures and commonly is relied upon by courts in interpreting and applying the law.

When the institute undertook its work on criminal law, however, it judged the existing law too chaotic and irrational to merit "restatement." What was needed, the institute concluded, was a model code, which states might use to draft new criminal codes.

The institute's criminal law work was started in 1931, a year after the institute completed a model code of criminal procedure. But the work was stalled during the depression years by lack of adequate funding and later by the events surrounding World War II. It was renewed in I95I with a grant from a private foundation and proceeded at full speed for more than a decade.

From the beginning, the project bore the imprint of the Chief Reporter, Herbert Wechsler, a law professor at Columbia University who also had participated in the Nuremberg trials of Nazi war criminals. ${ }^{13}$ Wechsler assembled a distinguished and remarkably diverse advisory committee of law professors, judges, lawyers, and prison officials, as well as experts from the fields of psychiatry, criminology, and even English literature. ${ }^{14}$ In addition, a number of drafting groups tackled various

I2. See La. Crim. Code (1942).

13. On Wechsler's approach to criminal law codification, see Herbert Wechsler, The Challenge of a Model Penal Code, 65 Harv. L. Rev. I097 (1952).

14. Jerome Hall, the leading American criminal law theorist of the time, did not meaningfully participate in the drafting of the code. Cf. Jerome Hall, The Proposal to Prepare a Model Penal Code, 4 J. Legal Stud. 9I (I95I); see also Markus D. Dubber, Penal Panopticon: The Idea of a Modern Model Penal Code, 4 Buff. Crim. L. Rev. 53, 63-64 (2000) (discussing Wechsler's rejection of Hall's retributivism). 
specific topics, such as the treatment of insane offenders or the death penalty. After much debate within the drafting group and the advisory committee, tentative drafts of parts of the code with detailed commentary were presented to and debated by the entire membership of the institute at its annual meetings. This process of annually considering tentative drafts continued until 1962, when the institute finally approved a complete Proposed Official Draft. The original drafters' commentaries contained in the various tentative drafts were consolidated, revised, and finally republished along with the 1962 text as a six-volume set in $1985 .{ }^{15}$

The diversity of its advisory committee indicates the almost Livingstonian scope of the Model Penal Code's ambition. The Model Penal Code is not merely a criminal code, but rather extends to the law governing the infliction of punishment. In fact, the code refers to itself as a "Penal and Correctional Code" or P.C.C., with its first two parts dedicated to substantive criminal law and the other two parts addressing "treatment and correction" and "organization of correction," respectively. ${ }^{16}$ No part of the Model Penal Code is explicitly devoted to the remaining aspect of penal law, the law of criminal procedure and evidence. Nonetheless, the code is littered with procedural provisions, including sections that determine the method and propriety of prosecution in particular cases; ${ }^{17}$ address the defendant's competency to stand trial $;{ }^{18}$ define, assign, and shift the burden of proof; $; 9$ establish evidentiary presumptions; ${ }^{20}$ and deal with the appointment of expert witnesses. ${ }^{21}$ These provisions complement the ALI's 1930 Model Code of Criminal Procedure. Ten years after the completion of the Model Penal Code, the ALI also published a Model Code of Pre-Arraignment Procedure.

While the Model Penal Code acknowledged the importance of retributional concerns, it commonly gave prominence to more utilitarian

I5. Model Penal Code (Official Draft and Revised Comments 1985).

I6. Id. $\$$ I.OI(I).

I7. Id. $\$ \$$ I.07-.II, 2.I2.

I8. Id. $\$ 4.04$.

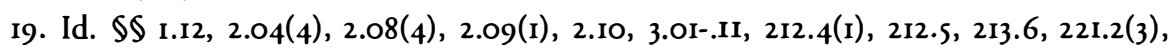
223.I(I), 223.4, 223.9, 230.3, 242.5.

20. Id. $\$ \$$ I.03(4), I.I2(5), 5.03(7), 5.06(2) \& (3), 5.07, 210.2(b), 211.2, 212.4, 223.6(2), $223.7(\mathrm{I}), 223.8,224.5,251.2(4), 251.4$.

2I. Id. $\$ 4.05$. 
functions: to deter criminal conduct and, in the event this failed, to diagnose the correctional and incapacitative needs of each offender. ${ }^{22}$ The Model Penal Code in this way laid the foundation for the Correctional Code. ${ }^{23}$ For example, the Model Penal Code prescribes the same peno-correctional treatment for a person who attempts to commit an offense as for a person who manages to consummate the offense, because both undeterred offenders have displayed the same symptom of dangerousness. ${ }^{24}$

Still, it cannot be said that the Model Penal Code systematically worked out the implications of any particular theory of punishment (or treatment). Adopting an approach that has been characterized as "principled pragmatism," ${ }^{25}$ the code drafters never lost sight of the code's ultimate goal, the reform of American criminal law. Instead of rewriting criminal law in strict consequentialist terms, the code drafters took care to ground the code firmly in existing law and frequently sacrificed theoretical consistency for pragmatic expediency. To continue with the example of attempt, the Model Penal Code carved out an exception for serious offenses, to blunt the otherwise radical impact of its new principle of equal treatment for attempted and consummated offenses. ${ }^{26}$ Similarly, the code did not condemn capital punishment, the one sanction that could not fit into its law of "treatment and correction." Instead, it addressed the question in a bracketed section that imposes many serious restrictions on the imposition of capital punishment. ${ }^{27}$ Ironically, this conflicted provision later became the foundation for several death penalty statutes and, eventually, the United States Supreme Court's effort to place capital punishment on a constitutional foundation. ${ }^{28}$

22. The purposes of the code's various parts are defined in id. $\oint$ I.O2(I) \& (2). See generally Dubber, supra note 14; Robinson, supra note 2, $\$$ I.2.

23. Model Penal Code pts. III \& IV (Proposed Official Draft 1962).

24. Model Penal Code $₫ 2.05$ cmt. at 293-95 (Official Draft and Revised Comments 1985).

25. Herbert L. Packer, The Model Penal Code and Beyond, 63 Colum. L. Rev. 594 (1963).

26. Model Penal Code $₫$ 5.0I(I) (Proposed Official Draft 1962).

27. Id. $\$ 210.6$.

28. See, e.g., McGautha v. California, 402 U.S. I83, 202 (1971); Gregg v. Georgia, 428 U.S. 153, 158, I90-9I, 194 (1976); Proffitt v. Florida, 428 U.S. 242, 247 (1976); California v. Ramos, 463 U.S. 992, 1009 (1983). 


\section{THE INFLUENCE OF THE MODEL PENAL CODE}

As a pragmatic document, the Model Penal Code enjoyed great success in American legislatures. The code's impact on American criminal law far exceeded that of even the most successful earlier codification project, the Field code. But it was the criminal law portion of the code - the statement of general principles of liability in part I and the definition of specific offenses in part II-that gained historic significance. The sentencing, treatment, and corrections portions, in parts III and IV, saw little acceptance and were soon left behind as American punishment theory and practice moved on to other approaches.

Even before the Model Penal Code was finished, its tentative drafts were used as models for criminal code reform. The two decades following the 1962 promulgation saw a host of state recodifications. New codes were enacted in Illinois, effective in 1962; Minnesota and New Mexico in 1963; New York in 1967; Georgia in 1969; Kansas in 1970; Connecticut in 1971; Colorado and Oregon in 1972; Delaware, Hawaii, New Hampshire, Pennsylvania, and Utah in 1973; Montana, Ohio, and Texas in 1974; Florida, Kentucky, North Dakota, and Virginia in 1975; Arkansas, Maine, and Washington in 1976; South Dakota and Indiana in 1977; Arizona and Iowa in 1978; Missouri, Nebraska, and New Jersey in 1979; Alabama and Alaska in 1980; and Wyoming in 1983. All of these thirty-four enactments were influenced in some part by the Model Penal Code. Draft criminal codes produced in other states, such as California, Massachusetts, Michigan, Oklahoma, Rhode Island, Tennessee, Vermont, and West Virginia, did not pass legislative review and may yet be revived.

Of the states that have not yet adopted a modern criminal code, the federal system is the most unfortunate example. The U.S. Congress has tried on and off to reform the federal criminal code since 1966, when Congress established a code revision commission at the urging of President Johnson..$^{29}$ In 1971, the Brown Commission produced a comprehensive and systematic Proposed New Federal Criminal Code. ${ }^{30}$ Later code proposals, built upon the Brown Commission model, were introduced as legislative bills. One of these bills even passed the Senate but died

29. See generally Ronald L. Gainer, Federal Criminal Code Reform: Past and Future, 2 Buff. Crim. L. Rev. 45 (1998).

30. National Commission on Reform of Federal Criminal Laws, Final Report: A Proposed New Federal Criminal Code (197I). 
in the House of Representatives. Criminal code reform is always difficult because it touches highly political issues, but the lack of a modern federal criminal code is considered a matter of some embarrassment among criminal law scholars in the United States. The present federal criminal code is not significantly different in form from the alphabetical listing of offenses that was typical of American codes in the r8oos.

The Model Penal Code's influence has not been confined to the reform of state codes. Thousands of court opinions have cited the Model Penal Code as persuasive authority for the interpretation of an existing statute or in the exercise of a court's occasional power to formulate a criminal law doctrine. (As is well known, while American courts have authority to interpret a code's ambiguous provisions, they generally are bound to follow what they know to be the legislative intention, and bound by interpretation decisions of a higher court.)

Even the Model Penal Code's official commentaries have been influential. Many states have little legislative history available for their courts to use in interpreting a state code provision. Where the state code provision was derived from or influenced by a Model Penal Code provision, the Model Penal Code's commentary often is the best available authority on the reasoning behind the provision and its intended effect.

The code's official commentaries also have become an important research source for criminal law scholars. The commentaries generally give a thoughtful and detailed explanation of the reasoning underlying a code provision as well as the scholarly debates concerning it. Also, because the official commentaries were not published until 1980 (Special Part) and 1985 (General Part), the commentary drafters had available to them information on how each of the Model Penal Code provisions fared during the previous two decades of state criminal code reform. The extent of a code provision's reception or rejection by the states often is detailed in the official commentaries.

The code's provisions for sentencing ${ }^{31}$ and treatment ${ }^{32}$ have not been influential..$^{33}$ They reflect a rehabilitative approach that has since passed out

31. Model Penal Code arts. $6 \& 7$ (Proposed Official Draft 1962).

32. Id. pts. III \& IV.

33. The American Law Institute is currently considering a revision of the code's sentencing provisions. See Symposium, Model Penal Code: Sentencing, 7 Buff. Crim. L. Rev. I-306 (2003); see also Kevin R. Reitz, American Law Institute, Model Penal Code: Sentencing, Plan for Revision, 6 Buff. Crim. L. Rev. 525 (2003). 
of favor. The code has many fewer grading categories than most modern American codes, thereby allowing greater sentencing discretion within each offense grade..$^{34}$ Its sentencing system generally relies upon the exercise of broad discretion by judges to individualize an offender's sentence.

In contrast, current American practice is to limit sentencing discretion. ${ }^{35}$ That change in approach comes in part from a belief that discretion undercuts the virtues of the legality principle: Discretion increases the likelihood of disparate sentences for similar offenders committing similar offenses. ${ }^{36}$ Discretion increases the potential for abuse by a biased decision maker. Discretion undercuts predictability, which is important for both effective deterrence and fair notice. Finally, discretion shifts the criminalization and punishment decisions away from the legislative branch and to the less democratic judicial and executive branches of government.

The code's discretionary sentencing system also is of little current influence in the U.S. because of a change in the underlying theory of liability and punishment. ${ }^{37}$ The code's use of discretion was consistent with its interest in using the criminal justice system to promote rehabilitation and to incapacitate dangerous offenders who could not be rehabilitated. With that purpose, the length of an offender's incarceration logically depended upon how the person changed during his criminal commitment. An actual release date could only be determined when an offender appeared to be ready for release.

The limited ability of the social sciences to rehabilitate and to reliably predict future dangerousness has dampened the interest in broad sentencing discretion. This, along with a growing interest in imposing just punishment, has led to less sentencing discretion and more determinate sentences (that is, sentences not subject to early release on parole).

This change in the underlying penal philosophy affected the legislative success not only of the code's sentencing and treatment provisions but also

34. See Gerard E. Lynch, Towards a Model Penal Code, Second (Federal?): The Challenge of the Special Part, 2 Buff. Crim. L. Rev. 297 (1998).

35. See, for example, the (once) mandatory sentencing guidelines for federal courts, United States Sentencing Guidelines Manual (2005). The future of determinate guideline sentencing in the United States, however, recently has been thrown into doubt. See United States v. Booker, 543 U.S. 220 (2005) (federal sentencing guidelines merely advisory).

36. See, e.g., Marvin E. Frankel, Criminal Sentences: Law Without Order (1973).

37. See, e.g., Andrew von Hirsch, Doing Justice: The Choice of Punishments (1976); Francis A. Allen, The Decline of the Rehabilitative Ideal: Penal Policy and Social Purpose (198I); Herbert Morris, Persons and Punishment, 52 Monist 475 (1968). 
of some of its liability and grading provisions. For example, few states have followed the code's abandonment of the common law distinction between the punishment for attempted and consummated offenses. The code's policy makes good sense if one's focus is on rehabilitation and incapacitation of the dangerous - an offender may be equally dangerous whether or not his conduct in fact causes the harm intended or risked. On the other hand, if the criminal law is to capture the community's sense of justice, then the community's shared intuition that resulting harm does matter cannot be ignored. ${ }^{38}$

The code's Special Part also has become dated in some areas, such as in its treatment of sexual offenses and drug offenses. American society's views on many sexual and gender issues have changed since the code was drafted in the I950s. Modern American codes typically adopt a gender-neutral approach to defining sexual offenses, give greater expression to the concern for victims of sexual offenses, and reflect a greater sensitivity to the history of sexual victimization of women by men. For instance, beginning in the I980s, states began to reject the marital immunity for rape, which the Model Penal Code had retained from the common law. At the same time, drug offenses now figure among the most serious offenses defined in American criminal codes. In 1962 the Model Penal Code included no drug offenses. In an appendix to the code's Special Part, the drafters merely remarked that "a State enacting a new Penal Code may insert additional Articles dealing with special topics such as narcotics, alcoholic beverages, gambling and offenses against tax and trade laws." ${ }^{39}$

\section{THE INNOVATIONS OF THE MODEL PENAL CODE}

To appreciate the Model Penal Code's contribution to criminal law codification in the United States, it is important to recall the embryonic state of the subject at the outset of the Model Penal Code project in the early I950s. The then most recent codification effort was that of the 1948 reform

38. Paul H. Robinson \& John M. Darley, Justice, Liability, and Blame: Community Views and the Criminal Law (1995); Paul H. Robinson, Competing Conceptions of Modern Desert: Vengeful, Deontological \& Empirical (forthcoming 2007); Paul H. Robinson \& John M. Darley, Intuitions of Justice: Implications for Criminal Law and Justice Policy (forthcoming 2007).

39. Model Penal Code app. (Proposed Official Draft 1962). 
of the federal criminal code, an alphabetical ordering of federal crimes for which, according to a contemporary observer, "the spadework was done by the hired hands of three commercial law-book publishers, on delegation from a congressional committee desirous of escaping the responsibility of hiring and supervising its own staff." 40

As a result, the Model Penal Code drafters had virtually no existing American criminal codes to which to turn, with the possible exception of the recently reformed criminal code of Louisiana. That code, however, could have only limited significance for a Model Penal Code of American criminal law because of the unique history and nature of Louisiana law, which alone among the states was rooted not in uncodified English common law, but in codified European civil law. Much of what the Model Penal Code introduced into the United States has long been common practice in European codes. But while the code's structure generally resembles that of many European codes, the extent to which these foreign codes more directly influenced the Model Penal Code is unclear. The strongest foreign influence on the code came in the person of Glanville Williams, a British criminal law expert on the uncodified English common law.

\section{A. A Comprehensive General Part}

The Model Penal Code drafters created a "General Part" that contains a set of general principles applicable to each of the specific offenses contained in the "Special Part" of the code. The general principles include such matters as general principles for imposing liability, general principles of defense, general inchoate offenses, etc. Such a structure, hardly revolutianry by European standards, provides greater clarity and sophistication while simultaneously simplifying the code. Instead of having to repeat the rules governing complicity, omission liability, culpability requirements, or available defenses, for example, in each offense (or leaving them to the courts to define), the rules can be stated once in detailed form in the General Part, to be referred to in the prosecution of any offense in the Special Part.

The current federal criminal "code" is typical of what existed in the states before the Model Penal Code. It has essentially no General Part. (The term "code" may suggest a document of greater coherence and planning than is present in the current federal "code," so it may be better

40. Henry M. Hart, Jr. The Aims of the Criminal Law, 23 Law \& Contemp. Probs. 40I, 432 n.70 (1958). 
to refer simply to "Title I8 of the United States Code"). Title I8's chapter 1, grandly titled "General Provisions," includes a less-than-helpful definition of complicity, an insanity defense, and a few definitions. Thus, 99 percent of the General Part remains uncodified in federal law, thereby delegating criminal-law making authority to the federal judiciary.

\section{B. An Analytic Structure}

The Model Penal Code, like most successful criminal codes, implicitly provides an analytic structure that gives judges, lawyers, and jurors a decisional process for assessing criminal liability. ${ }^{41}$ Its three-part structure might be summarized with these questions:

First, does the actor's conduct constitute a crime? The code defines the contours of the law's prohibitions (and, where duties to act are created, the law's commands). This is the issue most familiar to laypersons and most prominent in older criminal codes. It is the sole subject of the code's entire Special Part.

Second, even if the actor's conduct does constitute a crime, are there special reasons why that conduct ought not to be considered wrongful in this instance, under these facts? Article 3 of the Model Penal Code answers this question through the use of justification defenses. These defenses concede the violation of a prohibitory norm, but offer a countervailing justificatory norm that undercuts the propriety of liability on the special facts of the current situation.

Finally, even if the actor's conduct is a crime and is wrongful (unjustified), should the actor be held blameworthy for it? Is he or she deserving of criminal liability and punishment? This question is answered primarily by the excuse defenses and culpability requirements in articles 2 and 4 of the code. For example, wrongful conduct by an actor who is at the time insane or under duress or involuntarily intoxicated may not be sufficiently blameworthy to merit the condemnation of criminal conviction.

\section{Defining Offenses Fully, Using Defined Terms}

The Model Penal Code drafters understood that an undefined term invites judicial lawmaking in the same way as an absent or partial provision, and 
can as effectively undercut the goals of the legality principle. Every code will inevitably contain ambiguous language that must be interpreted by judges. A drafter's obligation, they believed, is to reserve that delegation of judicial authority to the instances in which it is not reasonably avoidable. Code terms that might reasonably be given different definitions by different readers ought to be defined.

With this view, the Model Penal Code drafters did much to fully define offenses and to define the terms they used in defining offenses; the code explicitly rejects common law offenses and bars judicial creation of offenses. ${ }^{42}$ In addition, the code's General Part includes definitions of commonly used terms that will then have the same meaning in every provision of the code. Defined terms also are contained at the beginning of many articles in the Special Part.

Compared to many European criminal codes, the Model Penal Code covers more topics in greater detail. As a result, the code occasionally reads more like a criminal law textbook than a code. Its comprehensiveness and detail reflect the scope and nature of the code's reform ambition. Topics can be left for judicial or scholarly interpretation only in the presence of a highly sophisticated judiciary and academic community. At the time of the code project, the criminal law in the United States met neither of these conditions. The code, after all, was specifically designed to wrest the criminal law out of the hands of the judiciary which, after centuries of common-law making, had left the criminal law an unprincipled mess.

\section{A System for the Interpretation of Code Provisions}

The Model Penal Code drafters' concern for advancing legality interests also showed in their creation of a system for the interpretation of the code's provisions. Such guidance in the exercise of judicial discretion increases the law's predictability and reduces both disparity in application and the potential for abuse of discretion.

The statutory principles of interpretation also are designed to advance the goals for which criminal liability and punishment are imposed. Model Penal Code section I.O2 directs judges to interpret ambiguous provisions

42. Model Penal Code $₫$ r.os (Proposed Official Draft 1962). 
to further the code's purposes. ${ }^{43}$ While such a provision has its shortcomings (it gives no guidance on what to do when different purposes conflict, as frequently occurs), it is an important first step toward rationality in code drafting, for it offers a formal statement of what the code is meant to achieve.

\section{E. A System of Offenses}

Rather than a collection of offenses, where each offense is an independent creature, often the result of a political campaign prompted by a particular crime or event, the Model Penal Code adopts a system of offenses, in which offenses are designed to work together as a complementary group. Offenses typically avoid both gaps and overlaps in coverage. By considering all offenses together, the legislature can better insure that the penalties associated with each offense properly reflect the relative seriousness of that offense in relation to other offenses.

Part of this systematic approach to creating and defining offenses is to organize offenses conceptually_offenses against the person, offenses against property, etc. - and within each general group to organize offenses into related subcategories. ${ }^{44}$ Offenses against the person, for example, are organized into four articles: homicide ( $\$ 2 \mathrm{IO})$; assault, endangerment, and threats $(\$ 2 \mathrm{II})$; kidnapping and related offenses $(\$ 2 \mathrm{I} 2)$; and sexual offenses $(\$ 213)$. Such conceptual grouping makes it easier to see, and to avoid, overlaps among offenses and unwarranted grading disparities. It also makes it easier for a code user to find the relevant offense. And, when the relevant offense is found, such grouping insures the user that related offenses are nearby, not hidden in a dark corner elsewhere in the code.

43. The code's purposes are:

(a) to forbid and prevent conduct that unjustifiably and inexcusably inflicts or threatens substantial harm to individual or public interests; (b) to subject to public control persons whose conduct indicates that they are disposed to commit crimes; (c) to safeguard conduct that is without fault from condemnation as criminal; (d) to give fair warning of the nature of the conduct declared to constitute an offense; (e) to differentiate on reasonable grounds between serious and minor offenses.

Model Penal Code $\bigotimes$ r.o2(I)(a)-(e) (Proposed Official Draft 1962).

44. For a comparative discussion of the code's notion of "individual or public interests" and the concept of Rechtsgut in German criminal law, see Markus D. Dubber, Theories of Crime and Punishment in German Criminal Law, 53 Am. J. Comp. L. 679 (2006). 


\section{F. Innovations in Specific Criminal Law Doctrines}

In substance, the Model Penal Code is based on the American criminal law at the time it was drafted. For the vast majority of issues in the general and special part of criminal law, this law was judge-made common law. If the code drafters ventured beyond the confines of American criminal law, they consulted English common law jurisprudence, particularly as interpreted by Glanville Williams, whose extended project to rationalize English criminal law coincided with Herbert Wechsler's attempt to rationalize American criminal law through the Model Penal Code. ${ }^{45}$

Many of the Model Penal Code's substantive innovations already were laid out in Wechsler's monumental 1937 article, "A Rationale of the Law of Homicide." "T6 There Wechsler, and his Columbia colleague Jerome Michael, subjected American criminal law to a detailed critique, using the law of homicide as an illustration. The Model Penal Code thus arose from a painstaking critique of positive law, rather than from a systematic theory of criminal liability. Wechsler was no theoretician. As a major figure in the American legal process school, Wechsler saw the problems of substantive criminal law as problems of policy. The criminal law, and therefore the Model Penal Code, was a means to achieve a policy end. ${ }^{47}$

\section{Offense Elements}

The Model Penal Code set out to simplify and rationalize the hodgepodge of common law offense definitions in two ways. ${ }^{48}$ First, it adopted an approach that has been called "element analysis," which carefully distinguished between the various elements of an offense, including conduct, attendant circumstances, and its result. Second, it recognized and defined only four mental states: purpose, knowledge, recklessness, and negligence. Each objective element of a given offense in the code can have attached to it a different mental state.

45. See Glanville Williams, Criminal Law: The General Part (1st ed. 1953; 2d ed. 1962). 46. Jerome Michael \& Herbert Wechsler, A Rationale of the Law of Homicide I \& II, 37 Colum. L. Rev. 701, 1261 (1937).

47. That end, however, in Wechsler's opinion, recently had been scientifically settled once and for all in favor of a deterrent-rehabilitative approach. See id. at 732 n.r26.

48. Paul H. Robinson \& Jane A. Grall, Element Analysis in Defining Criminal Liability, 35 Stan. L. Rev. 68I (1983); Robinson, supra note 4I, ch. 3. 
The first innovation was designed to eliminate the common law's confusion about the so-called mens rea of a given offense. This confusion, the code drafters believed, often resulted from the inability of the common law to distinguish between different elements of an offense, each of which may require a different mental state for conviction.

Standing alone, the differentiation of various offense elements, coupled with the novel requirement that each element, rather than merely each offense, carry a mental state, might have complicated rather than simplified the law. The second innovation addressed this problem by replacing the dozens of mental states that had emerged over the course of the common law with merely four.

This radical change in the law of mens rea, one of the core principles of the common law, drew little criticism from commentators and proved remarkably popular among state legislatures. ${ }^{49}$ In fact, the Model Penal Code's definitions of these four mental states may be the code's most important contribution to American criminal law reform. These definitions strove to simplify not only by radically reducing the number of mental states, but also by reducing (but not eliminating) reliance upon normative judgments. Talk of "malice aforethought" and even "premeditation" were replaced by presumably testable phenomena such as "conscious object" or "knowledge." In its zeal to clarify the law, the Model Penal Code even excised the words "intent" and "intention" from its terminology, concepts that in spite (or perhaps partly because) of their ambiguity had assumed a central place in the criminal law of the United States, as well as of many other countries..$^{50}$

On the subject of so-called strict or absolute liability offenses, i.e., offenses whose elements do not all require a culpability state, the Model Penal Code struck a characteristically pragmatic compromise. Instead of eliminating such offenses altogether, it limited their common use to two offense categories, "civil offenses" defined in the criminal code as "violations," punishable only by fine, forfeiture, or other civil penalty, and "offenses defined by statutes other than the code, insofar as a legislative purpose to impose absolute liability for such offenses or with respect to

49. But see Jerome Hall, Negligent Behavior Should Be Excluded from Penal Liability, 63 Colum. L. Rev. 632 (1963).

50. But cf. N.Y. Penal Law $\$ IS.05(I) (2006) (retaining mental state of "intentional," but redefining it in terms of "conscious objective"). 
any material element thereof plainly appears." ${ }^{51}$ The Model Penal Code does not prohibit strict liability in the code's offenses, but does create a presumption against interpreting the absence of a culpability element as strict liability. Instead, a requirement of recklessness is read into an offense that contains no specific culpable state of mind requirement. ${ }^{52}$

In the particular case of felony murder, a serious strict liability offense under the common law whose definition required no mental state with respect to the act of homicide, the Model Penal Code transformed the definitional question into an evidentiary one. Instead of eliminating the requirement of a mental state with respect to the homicidal act, as the common law had done, the code instead established a rebuttable presumption that the perpetrator of an underlying felony in fact had the mental state with respect to the killing that would constitute murder (recklessness manifesting an extreme indifference to the value of human life)..$^{53}$

\section{Inchoate and Accomplice Liability}

The Model Penal Code's abandonment of the common law distinction between inchoate and consummated offenses already has been mentioned. ${ }^{54}$ This decision was both the most doctrinaire and the least successful by the code drafters. Punishing inchoate offenses as harshly as consummated ones appears particularly harsh against the background of the wide sweep of inchoate offenses under the code. By defining all inchoate offenses in its General Part, the code cemented the common law's broad approach to preparatory offenses. Every crime, including the pettiest misdemeanor, was criminalized in its inchoate form, whether as an attempt, a solicitation, or as a conspiracy. Still, the Model Penal Code did bar the conviction of, though not the prosecution for, both the inchoate and the consummated form of an offense. 55 The code thereby rejected the most expansive theory of inchoate offenses under the common law, still espoused at the time by federal criminal law, which had permitted separate punishments for the preparation and consummation

51. Model Penal Code $₫$ 2.05 (Proposed Official Draft 1962).

52. Id. $\$ 2.02(3)$.

53. Id. $\$ 210.2(\mathrm{I})(\mathrm{b})$.

54. See generally Herbert Wechsler et al., The Treatment of Inchoate Crimes in the Model Penal Code I \& II, 6I Colum. L. Rev. 57I, 957 (196I).

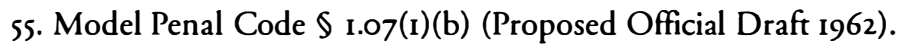


of the same offense. ${ }^{56}$ The code also prohibits multiple convictions "of more than one [inchoate] offense ... for conduct designed to commit or to culminate in the commission of the same crime." 57

The Model Penal Code draws a sharp theoretical distinction between inchoate offenses and complicity, which was defined as the attribution of the principal's criminal conduct to another. ${ }^{58}$ The distinction was of less practical significance, however, as the code abandoned not only the distinction between the punishment for preparatory and consummated offenses, but also that between the punishment of principals and accessories. In fact, the code discarded the common law distinctions between first- and second-degree principals, on the one hand, and accessories before and after the fact, on the other, in favor of a single distinction between principal and accomplice, both of whom were then subjected to the same punishment. ${ }^{59}$

Only after an intervention by Judge Learned Hand, one of America's most prominent judges, did the American Law Institute reject the drafters' proposal to extend accomplice liability, and therefore full punishment as a principal, to a person who was merely aware of his contribution to the principal's criminal act. ${ }^{60}$ The code instead requires that the accomplice act "with the purpose of promoting or facilitating the commission of the offense." ${ }^{\prime 11}$ As a compromise, some states have adopted general facilitation provisions that criminalize aiding another's criminal conduct knowingly or merely "believing it probable" that one is rendering aid. ${ }^{62}$

\section{Justification Defenses}

The code for the first time recognized a general defense of necessity, or lesser evils. This defense is available where particular justification defenses, such as self-defense, defense of property, or law enforcement authority,

56. See, e.g., Callanan v. United States, 364 U.S. 587 (1961).

57. Model Penal Code $\$ 5.05(3)$ (Proposed Official Draft 1962).

58. See id. $\$ 2.06$.

59. On the common law of complicity, see Francis Bowes Sayre, Criminal Responsibility for the Acts of Another, 43 Harv. L. Rev. 689 (1930).

6o. Model Penal Code $\$ 2.06 \mathrm{cmt}$. at 313-19 (Official Draft and Revised Comments 1985).

6r. Model Penal Code $\$$ 2.06(3)(a) (Proposed Official Draft 1962).

62. N.Y. Penal Law $\$ irs.00 (2006). 
are not. The defense applies to conduct the actor believes to be "necessary to avoid a harm or evil to himself or another," provided that "the harm or evil sought to be avoided by such conduct is greater than that sought to be prevented by the law defining the offense charged." ${ }^{3}$ The broad scope of this provision is best illustrated by the cases enumerated in the official code commentary:

Under this section, property may be destroyed to prevent the spread of a fire. A speed limit may be violated in pursuing a suspected criminal. An ambulance may pass a traffic light. Mountain climbers lost in a storm may take refuge in a house or may appropriate provisions. Cargo may be jettisoned or an embargo violated to preserve the vessel. An alien may violate a curfew in order to reach an air raid shelter. A druggist may dispense a drug without the requisite prescription to alleviate grave distress in an emergency. ${ }^{64}$

The lesser evils defense does not affect the actor's civil liability and is a socalled affirmative defense. To successfully invoke an affirmative defense, the defendant must produce supporting evidence before the burden of proof shifts to the prosecution, which must then disprove the defense beyond a reasonable doubt. ${ }^{65}$ The code frequently relies on this procedural mechanism to resolve difficult issues of substantive criminal law. ${ }^{66}$

\section{Excuse Defenses}

The Model Penal Code drafters devoted almost an entire article to the problem of legal insanity. Except for its final section, which sets the age of maturity for purposes of criminal liability at sixteen, ${ }^{67}$ article 4 deals in great detail with the full panoply of substantive and procedural issues surrounding the defense of insanity, including such procedural questions as the defendant's competency to stand trial, the assignment of the burden of proof, the requirement of notice that an insanity defense will be offered, the form of the verdict and judgment, the appointment and selection of

63. Model Penal Code $₫$ 3.02(I) (Proposed Official Draft 1962).

64. Model Penal Code $₫$ I.OI cmt. at 9-IO (Official Draft and Revised Comments 1985).

65. Model Penal Code $\$ \$$ I.I2, 3.0I (Proposed Official Draft 1962).

66. See sections cited supra note Io.

67. Model Penal Code $₫$ 4.IO (Proposed Official Draft 1962). 
psychiatric experts, the admissibility of statements made during the examination, the form of the psychiatrist's report, the hearing on the question of insanity or competency, and the commitment following an acquittal on the basis of insanity.

The Model Penal Code's extensive coverage of mental illness reflects the conflicts surrounding this issue during the decade of the code's drafting. The advisory committee included several members of the "Group for the Advancement of Psychiatry," whose members were determined to radically reform the criminal law in the name of the science of psychiatry. In 1954, three years into the code project, the federal appellate court for the District of Columbia, in the famous Durham case, ${ }^{68}$ replaced the so-called right-wrong test of insanity derived from the 1843 English case of $M^{\prime}$ Naghten $^{69}$ with a test designed to reflect advances in the field of psychiatry as well as to soften the perceived harshness of the M'Naghten rule.

Characteristically, the Model Penal Code once again struck a compromise by retaining but softening the M'Naghten test while assigning psychiatric experts a central role in the test's interpretation and application. The M'Naghten rule in its original formulation required that, "at the time of the committing of the act, the party accused was laboring under such a defect of reason, from disease of the mind, as not to know the nature and quality of the act he was doing; or, if he did know it, that he did not know he was doing what was wrong." The Model Penal Code extended the defense to an actor who "lacks substantial capacity ... to appreciate the criminality of his conduct."70 In addition, the Model Penal Code made the defense available even to an actor who did not qualify under this cognitive prong, as long as he lacked "substantial" volitional capacity "to conform his conduct to the requirements of law."

The Model Penal Code's insanity test proved popular in many American jurisdictions, including the District of Columbia after the abandonment of its Durham rule in $1972 .{ }^{72}$ Following John Hinckley's acquittal

68. Durham v. United States, 214 F.2d 862 (D.C. Cir. 1954). The Durham test was deceptively simple: "an accused is not criminally responsible if his unlawful act was the product of mental disease or mental defect." For later complications and the eventual demise of Durham, see United States v. Brawner, 47I F.2d 969 (1972) (en banc)

69. M'Naghten's Case, I C. \& K. 130; 4 St. Tr. N.S. 847 (1843).

70. Model Penal Code $₫ 4.01$ (Proposed Official Draft 1962).

7I. Id. $\$$ 4.or.

72. United States v. Brawner, 47I F.2d 969 (D.C. Cir. 1972) (en banc). 
under the volitional prong of the Model Penal Code's test for his assassination attempt on President Reagan in 198I, however, many states and the federal government restricted the defense of insanity by removing the volitional prong. ${ }^{73}$

\section{Special Part}

Most of the Model Penal Code's specific doctrinal innovations appeared in its General Part. The most important innovation in the Special Part was its revision of the law of homicide. The code's homicide article provides the best illustration of its new system of mental states. ${ }^{74}$ In this article, the code drafters replaced the common law's multitude of homicide offenses with a single offense- "purposely, knowingly, recklessly or negligently caus[ing] the death of another human being"-with three defined grades. Murder, manslaughter, and negligent homicide thus differed primarily in their mental state, the first requiring purpose or knowledge, the second recklessness, and the third negligence.

The code's partial rejection of the felony murder rule already has been discussed. The common law defense of provocation was retained, though not without being transformed into the more general defense of "extreme mental or emotional disturbance." 75 The code made no attempt to connect this def ense to other more general excuse defenses in its General Part. It therefore survives as a defense available only in homicide cases.

\section{CONCLUSION}

For almost half a century, the Model Penal Code has been the dominant force in American criminal code reform and a catalyst for American criminal law scholarship. In general, the Model Penal Code has stood the test of time. While individual provisions of the code, such as its definition of insanity and its grading of inchoate offenses, have been amended for one reason or another, no state has seen fit to undertake a wholesale reform of its criminal code away from the Model Penal Code. Even academic

73. See, e.g., Clark v. Arizona, 126 S. Ct. 2709 (2006).

74. Model Penal Code art. 210 (Proposed Official Draft 1962).

75. Id. $\$ 210.3(\mathrm{I})(\mathrm{b})$. 
commentary generally has come to focus on the code, albeit not always agreeing with it. ${ }^{76}$

Nonetheless, the code is showing its age as the theory and practice of American criminal law has long since rejected the code's emphasis on deterrence and rehabilitation and as attitudes toward criminalization have shifted. A reform of the model therefore is much needed. When that reform comes, however, there can be little doubt that it will build upon the foundations laid down in the Model Penal Code.

76. For collections of code commentary during its first twenty years, see Symposium, The Model Penal Code, 63 Colum. L. Rev. 589 (1963), and Symposium, The 25th Anniversary of the Model Penal Code, I9 Rutgers L.J. 519 (1988). For a more recent critical exchange regarding the Model Code, see George P. Fletcher, Dogmas of the Model Penal Code, 2 Buff. Crim. L. Rev. 3 (1998), and Paul H. Robinson, In Defense of the Model Penal Code: A Reply to Professor Fletcher, 2 Buff. Crim. L. Rev. 25 (1998). 